\title{
IPTEK Bagi Masyarakat Desa Tanjungpura Pada Budidaya Sayuran Menggunakan Metode Hidroponik Water Culture Dengan Memanfaatkan Media Limbah Anorganik
}

\author{
${ }^{1}$ Lissa Lissa ${ }^{1}$ Ismail Fikri Natadiwijaya ${ }^{1}$ Lesy Luzyawati \\ Prodi Pendidikan Biologi, IKIP Universitas Wiralodra, J1. Ir. H. Djuanda Km.03 Indramayu, \\ Jawa Barat, Indonesia
}

\section{Email Korespondensi: lesy.luzyawati@unwir.ac.id}

\begin{tabular}{|c|c|}
\hline Article Info & bstract \\
\hline $\begin{array}{l}\text { Article History } \\
\text { Received: } 2020-10-22 \\
\text { Revised: } 2020-10-29 \\
\text { Published: } 2020-10-30\end{array}$ & \multirow[b]{2}{*}{$\begin{array}{l}\text { Science and Technology for the Community of Tanjungpura Village in } \\
\text { Vegetable Cultivation Using the Hydroponic Water Culture Method Using } \\
\text { Inorganic Waste Media. The purpose of this activity is to educate the public } \\
\text { about the impact of inorganic waste on the environment, health benefits of } \\
\text { vegetables and provide training to utilize inorganic waste as a growing } \\
\text { medium for vegetable cultivation using hydroponic water culture techniques. } \\
\text { This service was carried out in Tanjungpura Village, Karangampel District, } \\
\text { Indramayu Regency, West Java. Styrofoam and used beverage bottles are } \\
\text { waste that have not been used and even become pollutants in the environment } \\
\text { besides that, Tanjungpura village has potential in the agrarian sector. The } \\
\text { implementation method uses PRA (Participatori Rural Appraisal). The results } \\
\text { of this PKM activity are 1) formation of public knowledge and understanding } \\
\text { of the impact of inorganic waste on the environment and the health benefits of } \\
\text { vegetables, 2) the formation of skills in processing inorganic waste into } \\
\text { planting media in vegetable cultivation using hydroponic water culture } \\
\text { techniques, 3) the formation of public concern for a clean environment and } \\
\text { health. In this activity, the inorganic waste used is still limited to used beverage } \\
\text { bottles and Styrofoam and the processing of the waste is only used for planting } \\
\text { media. so it is necessary to do other innovation efforts so that the waste used } \\
\text { and its processing is more varied. In addition, assistance is still needed to the } \\
\text { production, packaging and marketing stages of organic vegetables from } \\
\text { hydroponics. }\end{array}$} \\
\hline $\begin{array}{l}\text { Key } \\
\text { Scie } \\
\text { Cult } \\
\text { Hyd } \\
\text { Wat } \\
\text { Org }\end{array}$ & \\
\hline & \\
\hline Dipublikasi: 30- & \multirow{2}{*}{$\begin{array}{l}\text { Tujuan dari kegiatan pengabdian masyarakat ini adalah untuk mengedukasi } \\
\text { masyarakat tentang dampak limbah anorganik bagi lingkungan, manfaat } \\
\text { sayuran bagi kesehatan dan memberikan pelatihan untuk memanfaatkan limbah } \\
\text { anorganik berupa botol bekas minuman dan styrofoam sebagai media tanam } \\
\text { budidaya sayuran dengan teknik hidroponik water culture. Pengabdian ini } \\
\text { dilakukan di Desa Tanjungpura Kecamatan Karangampel Kabupaten } \\
\text { Indramayu, Jawa Barat. Styrofoam dan botol bekas minuman merupakan } \\
\text { limbah yang belum dimanfaatkan bahkan menjadi pencemar di lingkungan, } \\
\text { selain itu desa Tanjungpura memiliki potensi di bidang agraria. Metode } \\
\text { pelaksanaan menggunakan PRA (Participatori Rural Appraisal). Hasil dari } \\
\text { kegiatan PKM ini adalah 1)terbentuknya pegetahuan dan pemahaman } \\
\text { masyarakat tentang dampak limbah anorganik bagi lingkungan dan manfaat } \\
\text { sayuran bagi kesehatan, 2) terbentuknya keterampilan dalam mengolah limbah } \\
\text { anorganik menjadi media tanam pada budidaya sayuran dengan teknik } \\
\text { hidroponik water culture, 3)terbentuknya kepedulian masyarakat terhadap } \\
\text { lingkungan bersih dan kesehatan. Pada kegiatan ini limbah anorganik yang } \\
\text { digunakan masih sebatas botol bekas minuman dan styrofoam dan pengolahan }\end{array}$} \\
\hline $\begin{array}{l}\text { Ka } \\
\text { IPT } \\
\text { Buc } \\
\text { Hic } \\
W a \\
\text { Or\& }\end{array}$ & \\
\hline
\end{tabular}


limbahnya hanya digunakan untuk media tanam, sehingga perlu dilakukan usaha inovasi yang lain supaya limbah yang digunakan dan pengolahannya lebih variatif. Selain itu masih perlu dilakukan pendampingan sampai tahap produksi, pengemasan dan pemasaran sayuran organik dari hidroponik.

Sitasi: Lisa, Natadiwijaya F.I \& Luzyawati L. (2020) IPTEK Bagi Masyarakat Desa Tanjungpura Pada Budidaya Sayuran Menggunakan Metode Hidroponik Water Culture Dengan Memanfaatkan Media Limbah Anorganik. Sasambo: Jurnal Abdimas (Journal of Community Service). 2(3), 188195 DOI : DOI : $10.36312 /$ sasambo.v2i3.320

\section{PENDAHULUAN}

Desa Tanjungpura merupakan salah satu desa yang berada di Kecamatan Karangampel, Kabupaten Indramayu. Limbah anorganik berupa botol minuman dan styroform seperti layaknya di desa yang lain, disini pun melimpah karena sifat konsumtif masyarakat yang tinggi. Limbah tersebut berserakan tanpa dimanfaatkan oleh masyarakat sekitar sedangkan karakteristik dari botol minuman dan styroform itu sulit terurai sehingga akan mencemari ekosistem perairan dan lingkungan (Marliani, 2014). Berdasarkan survey yang dilakukan ke beberapa masyarakat desa Tanjungpura menyatakan bahwa tidak paham jika limbah anorganik itu akan berdampak negatif pada pertanian mereka. Kesadaran masyarakat akan bahaya limbah harus ditingkatkan, karena bukan hanya berakibat langsung bagi lingkungan tetapi juga bagi kesehatan. Oleh karena itu, perlu adanya usaha untuk menambah pengetahuan masyarakat akan bahaya limbah dan memanfaatkan limbah tersebut menjadi sesuatu yang memiliki nilai. Usaha tersebut dapat dilakukan dengan melakukan penyuluhan dan pelatihan pemanfaatan limbah anorganik sebagai media budidaya sayuran dengan teknik hidroponik.

Pada umumnya mata pencaharian utama masyarakat desa Tanjungpura adalah petani dari jumlah total penduduk \pm 5.200 jiwa yang berprofesi petani adalah $57 \%$ yaitu \pm 2.960 jiwa, sehingga menanam tanaman merupakan hal yang biasa mereka lakukan. Komoditi utama pertanian Kabupaten Indramayu adalah padi, karena padi merupakan tanaman yang dapat bertahan hidup dengan baik di kondisi lingkungan Indramayu (Mustikaningrum, 2018). Sedangkan sayuran merupakan tanaman yang jarang di tanam di Wilayah Indramayu karena faktor lingkungan yang kurang mendukung, yaitu diantaranya ketersediaan air tanah, cuaca dan struktur dan komposisi zat hara tanah (Widowati et al., 2018). Hal tersebut pun terjadi di Desa Tanjungpura kecamatan Karangampel, namun mengingat pentingnya fungsi sayuran yaitu sebagai asupan vitamin dan mineral di dalam tubuh (Hamidah, 2015) dan potensi masyarakat Tanjungpura terutama pada Kelompok Wanita Tani (KWT) Bunga Tanjung maka perlu dilakukan upaya pelatihan budidaya sayuran dengan memperhatikan kondisi lingkungan yang ada di Indramayu. Budidaya sayuran yang dapat diatur suhu, $\mathrm{pH}$, ketersediaan air dan hara adalah dengan teknik hidroponik.

Hidroponik menjadi alternatif bercocok tanam sayur pada lahan yang sempit dan cuaca yang panas. Hal ini dikarenakan dengan teknik hidroponik dapat diatur untuk suhu, $\mathrm{pH}$, dan ketersediaan nutrisi serta hemat dalam menggunakan lahan karena tidak membutuhkan tanah sebagai media tanamnya (Hidayat et al., 2018). Contoh sayuran yang biasanya ditanam dengan menggunakan hidroponik adalah sawi, bayam, selada, kangkung, tomat dan lain-lain (Swastika et al., 2018). Hidroponik adalah suatu metode bercocok tanam tanpa menggunakan media tanah, melainkan dengan menggunakan larutan mineral bernutrisi atau bahan lainnya yang mengandung unsur hara seperti sabut kelapa, serat mineral, pasir, pecahan batu bata, serbuk kayu, dan lain-lain sebagai pengganti media tanah (Susilawati, 2019). Hidroponik dapat mengasah kreativitas masyarakat untuk mengolah dan menciptakan media baru bercocok tanam dengan memanfaatkan barang yang ada atau barang bekas (Hidayat et al., 2018). Ada berbagai cara hidroponik yang dapat diterapkan diantaranya sistem sumbu (wick), 
sistem irigasi, hidroponik pasang surut, sistem NFT, rakit apung (water culture), sistem aeroponik (Susilawati, 2019).

Hidroponik dengan sistem water culture atau rakit apung adalah sistem yang paling sederhana dari semua sistem hidroponik aktif, cukup mudah digunakan karena tidak membutuhkan alat yang terlalu banyak, yang dibutuhkan box atau wadah yang dapat terbuat dari bahan plastik, styrofoam dan aerator. Hidroponik rakit apung merupakan pengembangan dari sistem bertanam hidroponik yang dapat digunakan untuk kepentingan komersial dengan skala besar ataupun skala rumah tangga (Susilawati, 2019). Dengan metode rakit apung, dapat memanfaatkan styrofoam dan botol bekas sebagai media tanamnya, dan metode ini pula merupakan metode yang cocok diterapkan pada Kelompok Wanita Tani (KWT) karena sistemnya sederhana dan dapat dilakukan di pekarangan rumah. Kelebihan sistem rakit apung adalah: 1) Biaya yang dibutuhkan tidak banyak karena bisa memanfaatkan alat dan bahan yang ada di rumah, 2) Alat dan bahan yang dibutuhkan cukup mudah ditemukan, 3) Perawatan sangat mudah, 4) Tidak terlalu bergantung pada suplai listrik, sehingga akan lebih menghemat pengeluaran, 5) Air dan nutrisi yang dibutuhka lebih sedikit, sehingga akan jauh lebih hemat. Di sisi lain sistem ini juga memiliki beberapa kekurangan yaitu, 1) Hanya bisa diaplikasikan di dalam ruangan, 2) Akar tanaman rentan membusuk karena terus tergenang (Swastika et al., 2018).

Adapun tujuan dari kegiatan pengabdian ini adalah memperkenalkan lingkungan bersih dan sehat dengan usaha pemanfaatan limbah botol bekas minuman dan styrofoam, memperkenalkan budidaya sayuran dengan hidroponik teknik water culture, dan melatih keterampilan masyarakat Desa Tanjungpura dalam budidaya sayuran dengan teknik hidroponik water culture dengan memanfaatkan limbah organik sebagai media tanam.

\section{METODE PELAKSANAAN}

Kegiatan pengabdian dilakukan pada Bulan Oktober - November 2020, bertempat di sekretariat Kelompok Wanita Tanita (KWT) Bunga Tanjung Desa Tanjungpura, dengan peserta 10 anggota Ibu-ibu KWT, KorWil Kecamatan Karangampel, dan Ketua Kelompok Tani Desa Tanjungpura. Metode yang digunakan pada kegiatan pengabdian ini adalah Participatori Rural Appraisal (PRA). PRA adalah suatu metode pendekatan dalam proses pemberdayaan dan peningkatan partisipasi masyarakat, yang tekanannya pada keterlibatan masyarakat dalam keseluruhan kegiatan (Pratiwi, 2007). Pelaku utama kegiatan adalah masyarakat sedangkan dosen sebagai fasilitator sehingga masyarakat bukan lagi sebagai objek. Berikut tahapan kegiatan yang dilakukan:

1. Pengenalan masalah/kebutukan dan potensi serta penyadaran

Kegiatan ini dilakukan dengan metode survey lapangan ke desa Tanjungpura dengan mewawancarai beberapa masyarakat terkait masalah dan potensi desa. Didapatkan limbah anorganik yang mencemari lingkungan dan potensi yang tergali adalah adanya kelompok ibu-ibu yang aktif di kegiatan bercocok tanam yaitu Kelompok Wanita Tani (KWT) bunga Tanjung.

2. Perencanaan penyelesaian masalah

Setelah mendapatkan masalah dan potensi desa, tim dosen berdiskusi untuk mengidentifikasi alternatif pemecahan masalah, merencanakan penerapan pemecahan solusi yang dipilih, dan merencanakan pengimplementasian program untuk menyelesaikan masalah. Tahapan ini meliputi koordinasi tim PkM untuk membahas Kerangka Acuan Kerja (KAK), persiapan alat dan bahan untuk kegiatan, pembuatan materi penyuluhan, penentuan tempat kegiatan, waktu pelaksanaan, dan peserta; dan pengurusan izin pelaksanaan kegiatan PkM. 
3. Penyuluhan

Penyuluhan atau pemaparan ilmu pengetahuan tentang Lingkungan bersih, bahaya limbah anorganik dan manfaat sayuran bagi kesehatan. Kegiatan ini dilakukan oleh tiga orang dosen Departemen Pendidikan Biologi Universitas Wiralodra.

4. Pelatihan

Pelatihan ini dilakukan secara langsung oleh peserta dengan didampingi oleh Dosen sebagai fasilitator kegiatan. Pelatihan ini bertujuan untuk meningkatkan keterampilan masyarakat dalam mengolah limbah anorganik sebagai media tanam budidaya sayuran dengan teknik hidroponik water culture.

5. Pendampingan kegiatan

Dosen Departemen Pendidikan Biologi Universitas Wiralodra mendampingi peserta pada semua tahap kegiatan PkM di Desa Tanjungpura. Peserta aktif bertanya dan berpendapat selama kegiatan berlangsung, sehingga terjadi komunikasi dua arah.

6. Evaluasi dan tindak lanjut kegiatan

Setelah dilakukan kegiatan maka tim PkM mengevaluasi kegiatan sehingga dapat diketahui kekurangannya pada tahap apa dan menindaklanjuti dengan perbaikan program yang akan dilakukan berikutnya.

Setelah dilakukan penyuluhan dan pelatihan masyarakat diberikan kuesioner untuk mencari respon masyarakat setelah kegiatan diselenggarakan. Mitra kegiatan pengabdian ini adalah Kelompok Wanita Tani (KWT) Bunga Tanjung Desa Tanjungpura yang berjumlah 10 Orang. Peran dari mitra dalam kegiatan adalah sebagai penyedia tempat kegiatan, peserta pada kegiatan penyuluhan dan pelatihan yang dilakukan oleh Universitas Wiralodra dan sebagai penyampai ilmu kepada masyarakat desa yang lainnya.

\section{HASIL DAN PEMBAHASAN}

Kegiatan PkM ini dilakukan pada hari Sabtu tanggal 31 Oktober 2020. Tujuan dari penyuluhan ini adalah untuk mengedukasi dampak limbah anorganik bagi lingkungan dan manfaat sayuran bagi kesehatan. Berdasarkan hasil kuesioner didapatkan temuan bahwa masyarakat membutuhkan informasi tentang lingkungan bersih dan kesehatan.

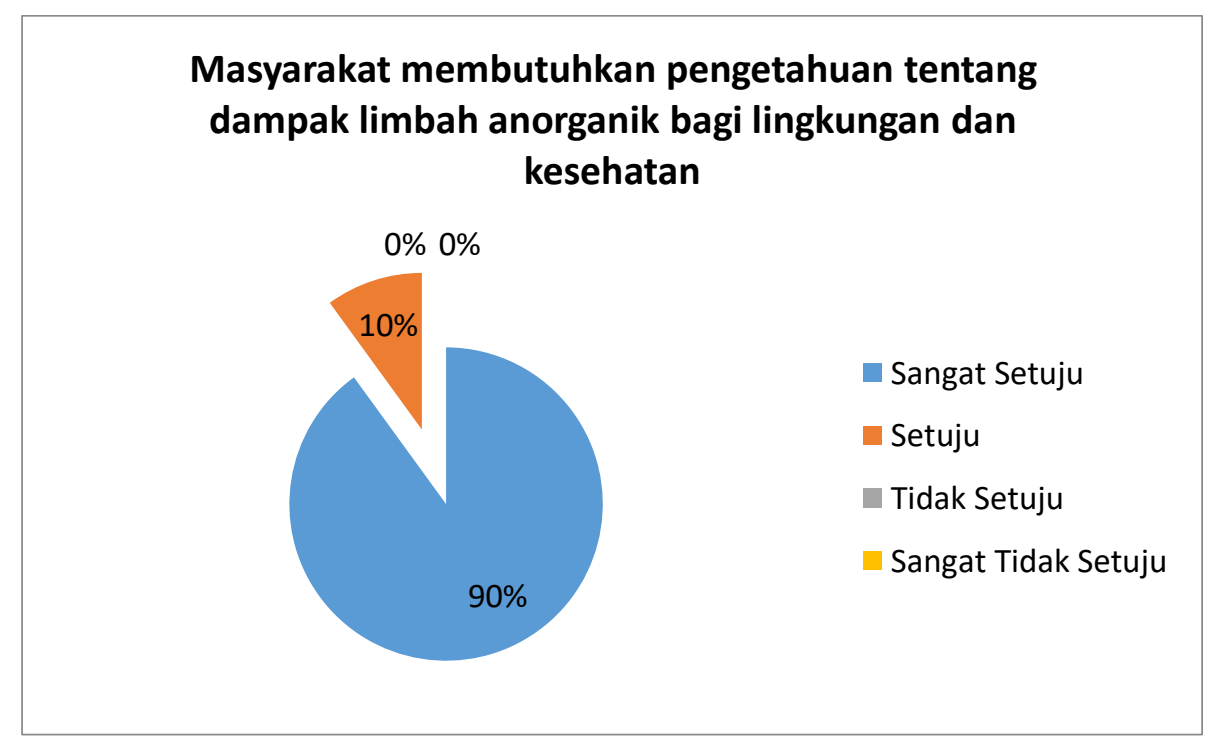

Gambar 1. Data Kebutuhan masyarakat

Berangkat dari data tersebut, maka dilakukan penyuluhan yang dihadiri oleh 10 orang anggota, ketua KWT, dan KorWil Kecamatan Karangampel bertempat di sekretariat KWT Bunga Tanjung Desa Tanjungpura Blok Tegalrasak, Kecamatan Karangampel, Kabupaten Indramayu. 

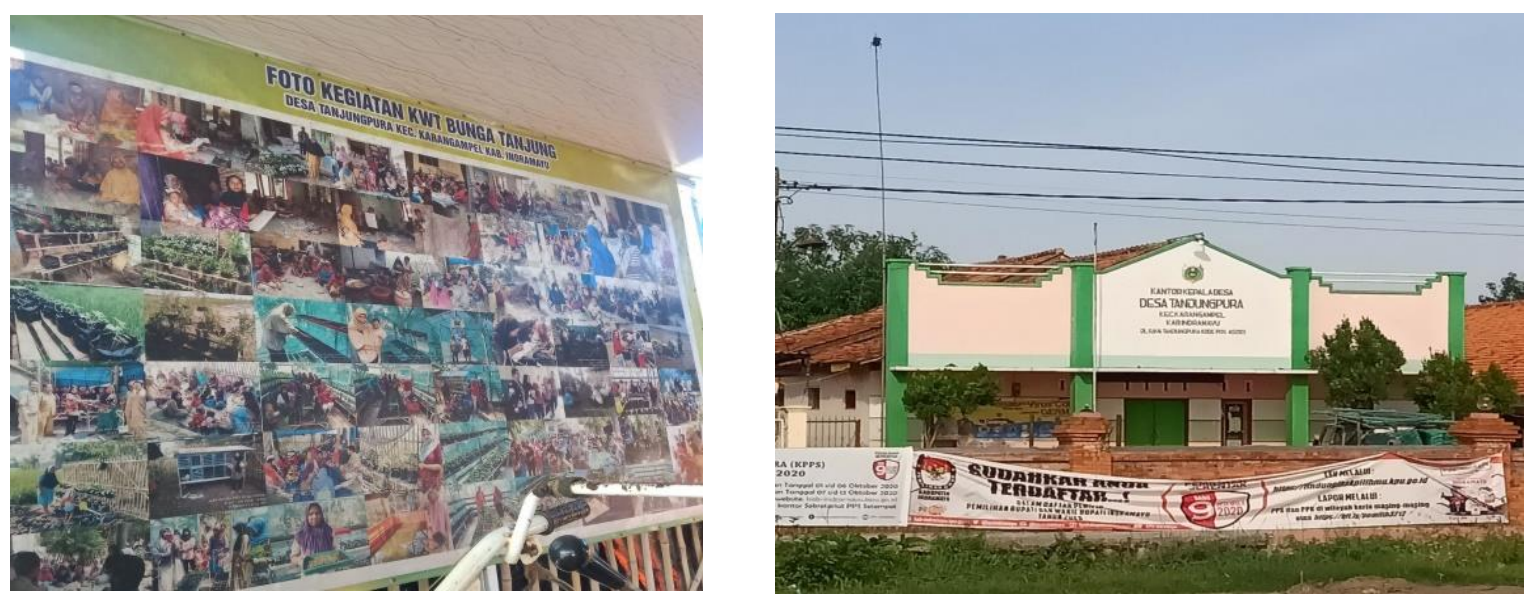

Gambar 2. a. Sekretariat KWT Bunga Tanjung, b. Balai Desa Tanjungpura

Materi penyuluhan yaitu tentang lingkungan bersih, bahaya limbah anorganik, dan manfaat sayuran bagi kesehatan tubuh. Proses penyuluhan berjalan lancar dan terjadi diskusi aktif antara pemateri dengan ibu-ibu KWT Bunga Tanjung hal tersebut menunjukkan motivasi dan keingintahuan yang tinggi yang dimiliki oleh ibu-ibu. Hal tersebut ditunjukkan dari hasil kuesioner yang menyatakan bahwa 100\% masyarakat menyatakan terjadi peningkatan pemahaman masyarakat setelah dilakukan penyuluhan. Masyarakat memiliki motivasi yang baik untuk membangun lingkungan yang bersih dengan memanfaatkan limbah anorganik yang berserakan menjadi produk yang bernilai ekonomi sehingga dapat meningkatkan kesejahteraan.

Sayuran merupakan tanaman yang sering ditanam oleh KWT namun sering gagal panen karena berbagai alasan diantaranya adalah adanya hama atau gagal pembentukan buah. Walaupun sering ditanam, ternyata manfaat sayuran bagi kesehatan masih begitu asing bagi ibu-ibu KWT. Oleh karena itu saat penyuluhan nampak keaktifan ibu-ibu dalam berdiskusi tentang manfaat sayuran dan kesehatan, contohnya adalah dengan pertanyaan "apakah penderita asam urat itu dikarenakan banyak memakan sayuran hijau?" ini karena banyak masyarakat dengan kadar asam urat yang tinggi dilarang mengkonsumsi sayuran hijau oleh dokter. Maka kami pun meluruskan pemahaman masyarakat tentang manfaat sayuran hijau bagi kesehatan tubuh, yaitu sebagai asupan vitamin dan mineral yang membantu proses metabolisme dalam tubuh sehingga dapat mengahasilkan energi dan memperbaiki sel-sel yang rusak, selain itu juga sebagai sumber serat yang melancarkan pencernaan makanan (Ichsan et al., 2015). Bahkan setelah penyuluhan, ibu-ibu berharap ada kajian rutin tentang lingkungan dan kesehatan sehingga mereka tidak salah memilih makanan yang dikonsumsi.
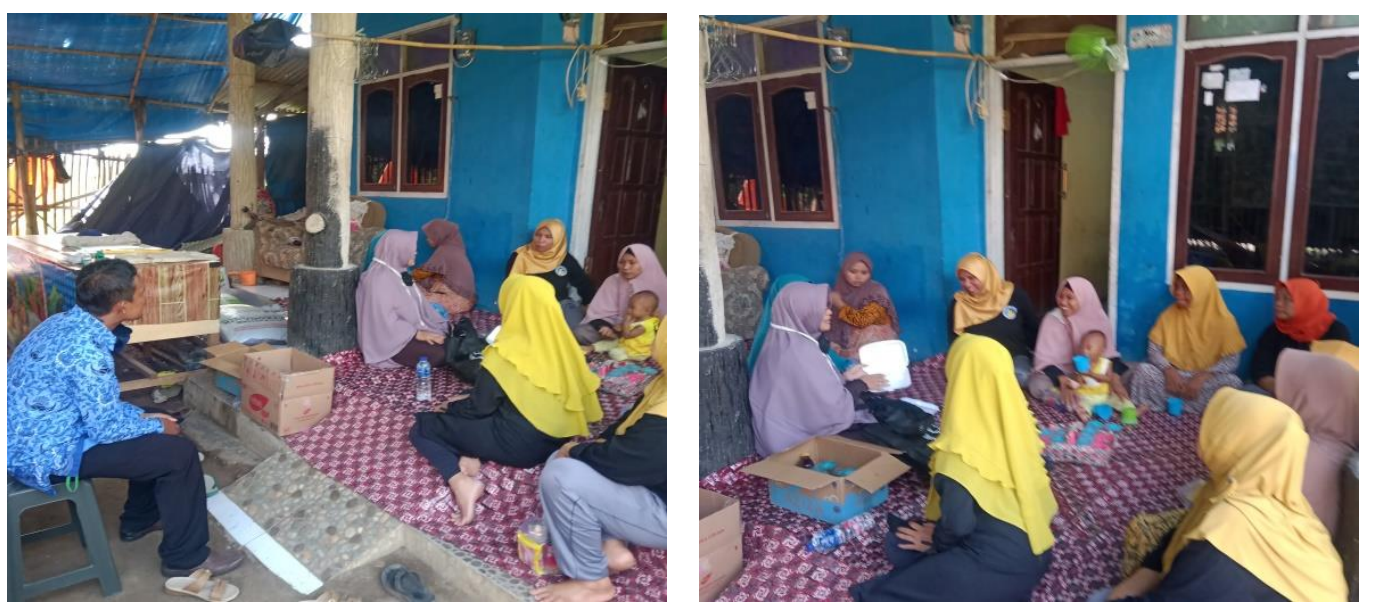

Gambar 3. a. Penyuluhan dampak limbah anorganik bagi lingkungan, b. Penyuluhan manfaat sayuran bagi kesehatan. 
Kegiatan penyuluhan dilakukan pada pagi hari dari pukul 10.00 sampai pukul 12.00 dan dilanjutkan pelatihan pada pukul 13.00 sampai pukul 16.00. Pelatihan pertama adalah pembuatan media tanam hidroponik dengan memanfaatkan limbah anorganik. Limbah anorganik biasanya digunakan untuk pembuatan kerajinan rumah tangga seperti tas dan vas bunga atau produk kreatif yang lain (Putra \& Yuriandala, 2010) yang dapat meningkatkan kesejahteraan masyarakat (Nugraha \& Suri, 2012). Limbah yang digunakan adalah styrofoam bungkus makanan, berbagai botol bekas minuman, dan plastik mika makanan. Dari satu Styrofoam dapat dibuat dua tempat tanam, cara pembuatannya dengan melubangi bagian atas sesuai dengan cetakan penyanggah tanaman yang disediakan. Sedangkan botol bekas minuman hanya dapat digunakan untuk 1 tanaman, caranya dengan menggunting leher botol kemudian membaliknya.
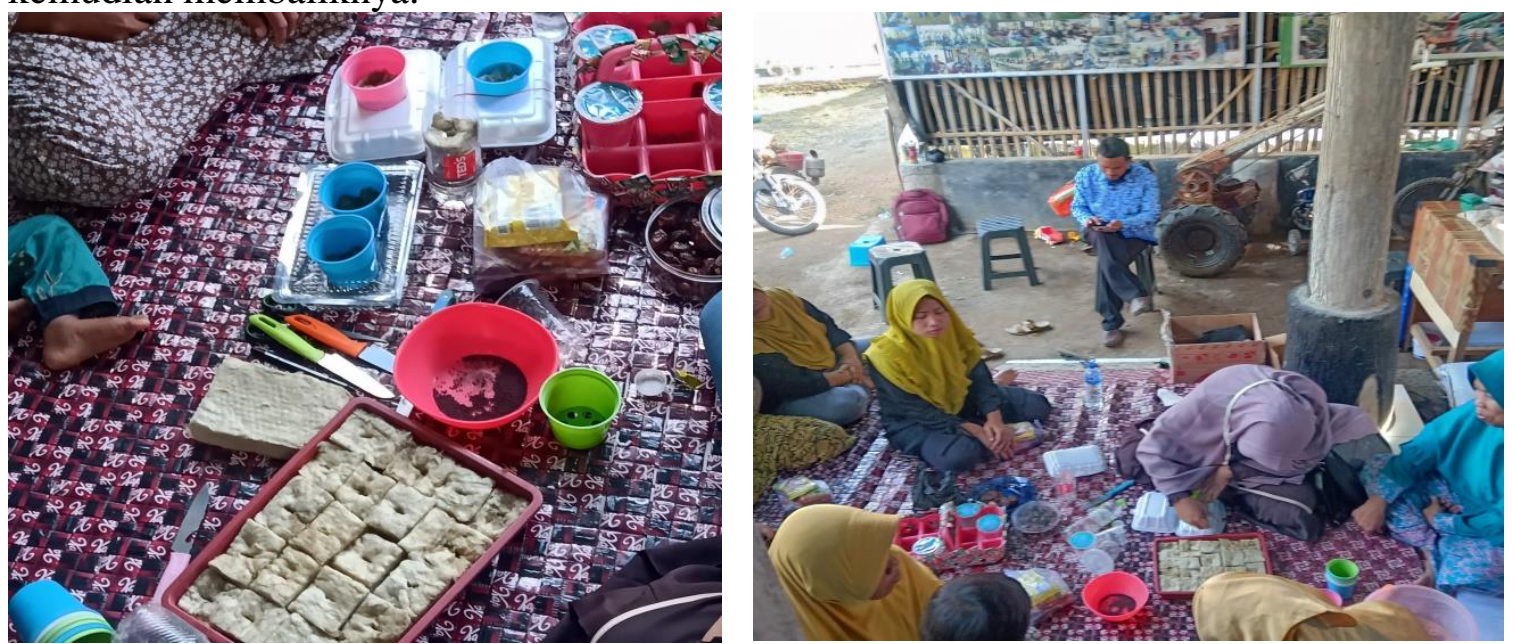

Gambar 4. a. Alat dan bahan pelatihan pengolahan limbah anorganik sebagai media tanam budidaya sayuran dengan teknik hidroponik, b. Pelatihan pembuatan media tanam hidroponik

Setelah media tanam siap, maka selanjutnya disiapkan rockwoll yang basah sesuai ukuran penyanggah tanaman. Praktek ini langsung dilakukan oleh ibu-ibu KWT Bunga Tanjung dengan bekerja secara berkelompok. Penanaman tidak langsung dilakukan dengan tanaman sayuran dewasa namun dari mulai mengecambahkan bibit dengan media rockwoll yang basah dan diletakkan sesuai dengan teknik hidroponik water culture atau rakit apung. Perkecambahan dengan media rockwoll akan tumbuh dalam waktu satu minggu, setelah itu tanaman sayuran dibudidayakan dengan teknik rakit apung, yaitu dengan menenggelamkan sebagian akar tanaman ke air yang tergenan, hal ini supaya oksigen tetap didapatkan oleh tanaman dan diberikan pompa air untuk sirkulasinya (Susilawati, 2019).

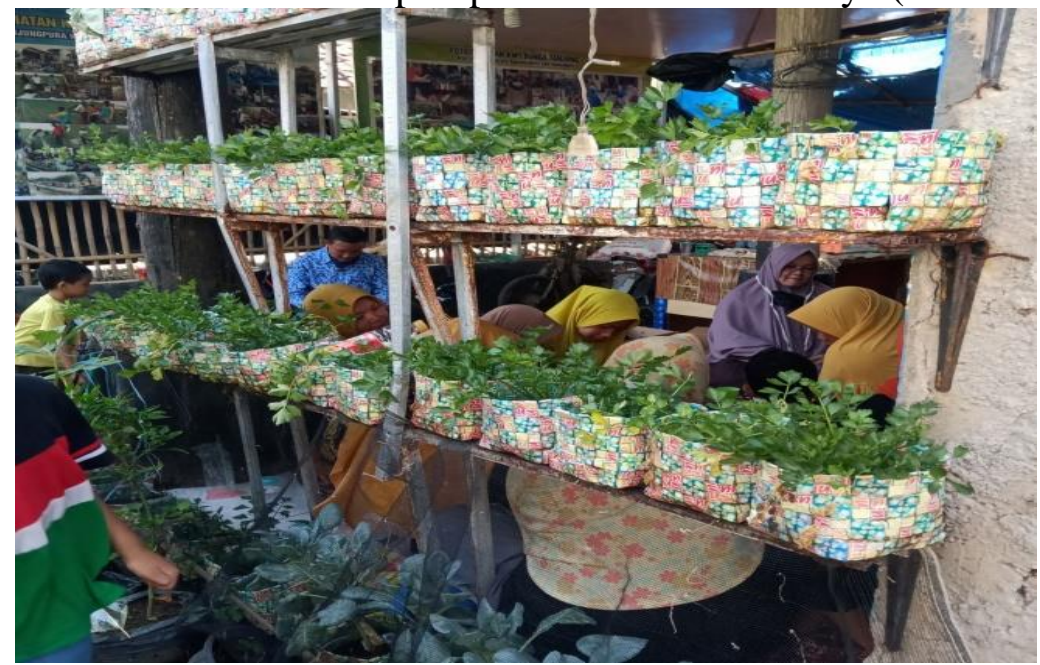

Gambar 6. Pelatihan budidaya sayuran teknik hidroponik water culture 
Setelah kegiatan pelatihan, ibu-ibu KWT Bunga Tanjung mendapatkan peningkatan keterampilan dalam membuat media tanam hidroponik dengan limbah anorganik dan teknik hidroponik water culture hal ini dikuatkan dari hasil kuesioner, yaitu $80 \%$ menyatakan Sangat Setuju (SS) dan 20\% Setuju (S). Selain itu juga dengan melihat dari hasil pelatihan yang telah dilakukan. Hidroponik dengan teknik rakit apung ini merupakan teknik yang sederhana sehingga mudah dipahami oleh ibu-ibu KWT Bunga Tanjung. Motivasi ibu-ibu KWT pun begitu tinggi terkait budidaya sayuran dengan hidroponik ini, bahkan $100 \%$ menyatakan perlu adanya kegiatan lanjutan yang berkesinambungan untuk mengembangkan budidaya sayuran dengan teknik hidroponik. Hal ini akan menjadi dasar dilakukannya kembali kegiatan lanjutan pengabdian pada masyarakat dari Universitas Wiralodra ke Kelompok Wanita Tani (KWT) Bunga Tanjung, Desa tanjungpura, Kecamatan Karangampel, Kabupaten Indramayu.

\section{Masyarakat membutuhkan kegiatan lanjutan}

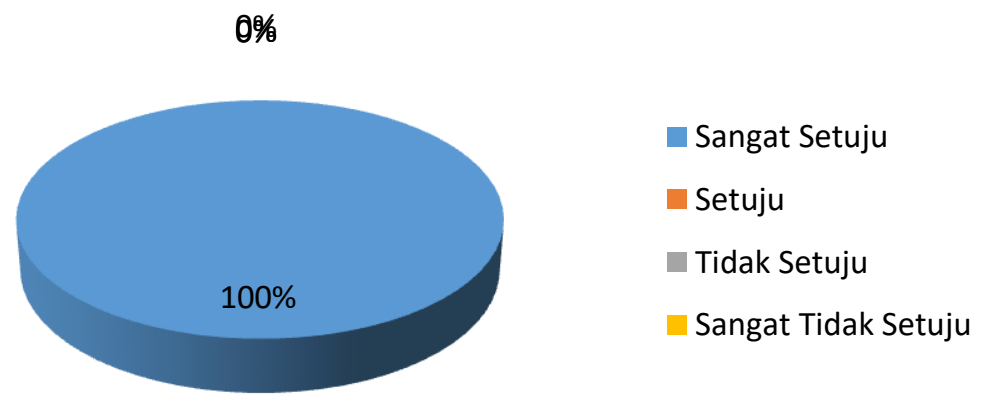

Gambar 6. Respon msyarakat setelah penyuluhan

\section{KESIMPULAN}

Kegiatan pengabdian yang dilakukan di Desa Tanjungpura ini berjalan lancar sesuai dengan perencanaan. Dapat disimpulkan bahwa masyarakat memahami tentang dampak limbah anorganik bagi lingkungan dan manfaat sayuran bagi kesehatan. Masyarakat juga lebih terampil dalam mengolah limbah anorganik menjadi media tanam untuk budidaya sayuran dengan teknik hidroponik metode water culture.

\section{SARAN}

Kegiatan pengabdian ini merupakan kegiatan awal sehingga dapat dilanjutkan dengan kegiatan yang berkesinambungan, misalnya dengan mengadakan pelatihan pembuatan pupuk organik hidroponik dengan memanfaatkan limbah organik, mengaktifkan produksi sayuran organik KWT Bung Tanjung melalui teknik pemasaran modern sehingga dapat mensejahterahkan masyarakat Tanjungpura.

\section{UCAPAN TERIMA KASIH}

Pelaksanaan kegiatan pengabdian ini tidak terlepas dari peran berbagai pihak, kami mengucapkan terima kasih kepada Rektor Universitas Wiralodra yang telah mendukung kegiatan ini, Ketua Lembaga Penelitian dan Pengabdian Kepada Masyarakat Universitas Wiralodra yang telah memberi dana hibah pada kegiatan ini, Dekan Fakultas Keguruan dan Ilmu Kependidikan Universitas Wiralodra yang telah memberi ijin kegiatan ini, Kepala Desa Tanjungpura Kecamatan Karangampel Kabupaten Indramayu yang telah merikan ijin untuk kegiatan pengabdian ini dan Kelompok Wanita Tani (KWT) Bunga Tanjung Desa Tanjungpura yang telah menjadi mitra pada kegiatan pengabdian ini. 


\section{DAFTAR PUSTAKA}

Hamidah, S. (2015). Sayuran dan Buah Serta Manfaatnya Bagi Kesehatan Disampaikan dalam Pengajian Jamaah Langar Mafaza Kotagede Yogyakarta. Fakultas Teknik Universitas Negeri Yogyakarta, 1-10. http://staffnew.uny.ac.id/upload/130799888/penelitian/sayuran.pdf

Hidayat, H., Sesanti, R. N., \& Maulida, D. (2018). Penerapan Budidaya Sayuran Dengan Sistem Hidroponik Mudah Dan Murah Di Rt 02 Dusun Sinar Jati Desa Hajimena Natar Lampung Selatan Implementation Of Vegetables Cultivation In Easy And Unexpensive Hydroponic Sistem At Rt 02 Dusun Sinar Jati Desa Hajimena Na. 2016, 16-23. https://core.ac.uk/download/pdf/327187667.pdf

Ichsan, B., Wibowo, B. H., \& Sidiq, M. N. (2015). Penyuluhan Pentingnya Sayuran Bagi Anak-Anak di TK AISYIYAH Kwandungan, Trowangsan, Malangjiwan, Colomadu, Karanganyar, Jawa Tengah. WARTA, 18(1), 29-35. http://journals.ums.ac.id/index.php/warta/article/viewFile/1164/749

Marliani, N. (2014). Pemanfaatan Limbah Rumah Tangga ( Sampah Anorganik ) Sebagai Bentuk Implementasi. Formatif, 4(2), 124-132. http://journal.lppmunindra.ac.id/index.php/Formatif/article/download/146/140

Mustikaningrum, I. (2018). Komoditas Unggulan Tanaman Pangan Untuk Mendukung Perekonomian Wilayah Kabupaten Indramayu Flagship Commodities of Food Crops to Support the Regional Economic in. 4(1), 57-65. https://ejournal2.undip.ac.id/index.php/ruang/article/view/2721/pdf

Nugraha, W. D., \& Suri, D. A. (2012). Studi Potensi Pemanfaatan Nilai Ekonomi Sampah Anorganik Melalui Konsep Daur Ulang Dalam Rangka Optimalisasi Pengelolaan Sampah (Studi Kasus: Kota Magelang). Teknik, 28(1), 9-20. https://doi.org/10.14710/teknik.v28i1.2077

Pratiwi, W. D. (2007). Participatory Rural Appraisal (PRA) SP 6102-Maret 2007 Wiwik D Pratiwi. http://dosen.ar.itb.ac.id/wdp/wp-content/uploads/2007/04/1-PRA-Indonesia.pdf

Putra, H. P., \& Yuriandala, Y. (2010). Studi Pemanfaatan Sampah Plastik Menjadi Produk dan Jasa Kreatif. Jurnal Sains \&Teknologi Lingkungan, 2(1), 21-31. https://doi.org/10.20885/jstl.vol2.iss1.art3

Susilawati. (2019). Dasar - Dasar Bertanam Secara Hidroponik | (I). UPT.Penerbit dan Percetakan Universitas Sriwijaya. https://repository.unsri.ac.id/26306/1/Buku Hidroponik edit.pdf

Swastika, S., Yulfida, A., \& Sumitro, Y. (2018). Budidaya Sayuran Hidroponik (Fahroji (ed.); Cetakan pe). Balai Pengkajian Teknologi Pertanian. http://riau.litbang.pertanian.go.id/kopitani/images/pdf/juknis/juknishidroponik.pdf

Widowati, R. ladiyani, Setyorini, D., Hartatik, W., Purnomo, J., Wiratno, haryati umi, \& Samsudin. (2018). Buku Sistem Budidaya Sayuran Organik2018.Pdf (J. dkk Purnomo (ed.); I). IAARD Press. http://balittanah.litbang.pertanian.go.id/ind/dokumentasi/lainnya/buku sistem budidaya sayuran organik2018.pdf 